\title{
APLIKASI KAMUS IRREGULAR VERBS BERBASIS ANDROID
}

\author{
Dang Anom ${ }^{1}$, Danuri ${ }^{2}$, Jaroji $^{3}$ \\ ${ }^{1}$ Program Studi Teknik Informatika, Politeknik Negeri Bengkalis \\ ${ }^{2,3}$ Program Studi Rekayasa Perangkat Lunak, Politeknik Negeri Bengkalis \\ $\underline{\text { danganom.rumada48@gmail.com }}{ }^{1}$, danuri@polbeng.ac.id ${ }^{2}$, jaroji@polbeng.ac.id ${ }^{3}$
}

\begin{tabular}{|c|c|}
\hline & Abstrak \\
\hline $\begin{array}{l}\text { Kata Kunci: } \\
\text { Android; Irregular } \\
\text { verbs; Java; Sqlite }\end{array}$ & $\begin{array}{l}\text { Irregular verbs adalah kata kerja dalam bahasa Inggris yang pembentukan lampaunya (past tense } \\
\text { atau past participle) tidak bisa ditambahkan dengan akhiran -ed atau-d melainkan kata tersebut } \\
\text { berubah sesuai kaidah yang ada. Cara mempelajari dan memahami nya hanya perlu menghafalkan } \\
\text { dari bentuk kata kerja dasar menjadi kata kerja ke dua dan ketiga, inilah yang menyebabkan banyak } \\
\text { orang mengalami kesulitan dalam mempelajari bahasa Inggris. Tujuan penelitian ini adalah } \\
\text { membuat aplikasi kamus irregular verbs berbasis android yang dapat dijadikan sebagai penunjang } \\
\text { dalam mempelajari bahasa Inggris khususnya irregular verbs. Perancangan aplikasi menggunakan } \\
\text { Unified Modelling Language, bahasa pemrograman java dan database sqlite. Penelitian ini } \\
\text { menghasilkan aplikasi kamus irregular verbs yang dapat digunakan pada perangkat mobile berbasis } \\
\text { android }\end{array}$ \\
\hline
\end{tabular}

\section{Abstract}

Keywords:

Android; Irregular

verbs; Java; Sqlite
Irregular is verbs on English do not add with ed or d but change agree with rule. To listen and comprehend only memorize from verb base make past tense and past participle. Because this result many people so think difficult in learning English specially of irregular verbs. Aim of this research is to make application dictionary irregular verbs base android to make support in listen English specially irregular verbs. Scheme of system use Unified Modelling Language, java programming and sqlite database. This research produce a application dictionary irregular verbs to use device mobile base android

\footnotetext{
$\bowtie$ Alamat korespondensi :

E-mail:

ISSN $: 2087-1627$
} 


\section{Pendahuluan}

Bahasa Inggris bisa dikatakan sebagai salah satu modal utama dalam menentukan keberhasilan seseorang dalam mendapatkan pekerjaan. Jika dilihat dari perkembangan teknologi saat ini, bahasa Inggris merupakan salah satu bahasa yang banyak digunakan dalam segala bidang teknologi. Ditambah lagi dengan adanya perdagangan bebas yaitu MEA (Masyarakat Ekonomi Asean) yang membuat seluruh negara yang tergabung dalam MEA (Indonesia, Malaysia, Filipina, Singapura, Thailand, Brunai Darussalam, Kamboja, Vietnam, Laos dan Myanmar) dapat melakukan perdagangan secara bebas. Tentu nya yang menjadi kendala untuk saling berkomunikasi adalah tidak memahami bahasa yang diucapkan antar satu negara dengan negara lainnya. Maka dari itu sangatlah penting untuk kita mempelajari bahasa Inggris yang akan dijadikan sebagai modal berkomunikasi di dalam pergaulan internasional karena Bahasa Inggris merupakan salah satu bahasa resmi di dunia dalam berkomunikasi [1].

Salah satu hal yang sulit dipelajari didalam bahasa Inggris adalah irregular verbs, irregular verbs adalah kata kerja dalam bahasa Inggris yang pembentukan lampaunya (past tense atau past participle) tidak bisa ditambahkan dengan akhiran $e d$ atau- $d$ melainkan kata tersebut berubah sesuai kaidah yang ada. Cara mempelajari dan memahami nya hanya perlu menghafalkan dari bentuk kata kerja dasar menjadi kata kerja ke dua dan ketiga [2], untuk mempermudahkan nya perlunya kamus baik yang berbentuk buku hingga berbentuk mobile. Pada saat ini banyak aplikasi kamus yang beredar telah menyertakan irregular verbs tetapi kata kerja yang tidak beraturan (irregular verbs) ini tidak dibahas secara keseluruhan serta tidak memberikan contoh - contoh penggunaan irregular verbs dalam kalimat yang sederhana.

Kamus adalah sejenis buku acuan yang tersusun berdasarkan abjad dan isinya terdiri dari kata-kata yang disertai dengan maknanya. Namun untuk saat ini banyak para pengguna kamus mengalami kendala dalam membawa kamus tersebut karena kamus ini biasanya besar dan hal ini tentu nya berat untuk dibawa kemana-mana[3]. Atas dasar ini perlunya dibuat sebuah aplikasi kamus irregular verbs berbasis android yang disertai dengan contoh - contohnya yang diharapkan akan membantu menjawab permasalahan yang dihadapi oleh para pelajar maupun orang umum yang ingin mempelajari bahasa Inggris khususnya irregular verbs.

\section{Tinjauan Pustaka}

\subsection{Irregular Verb}

Irregular verb merupakan salah satu dari bagian pokok Bahasa Inggris yang perlu bahkan wajib dipelajari, irregular verb adalah kata kerja yang mengalami perubahan dari bentuk dasar atau bentuk pertama menjadi bentuk ke dua dan ketiga atau irregular verbs adalah kata kerja dalam bahasa Inggris yang pembentukan lampaunya (past tense atau past participle) tidak bisa ditambahkan dengan akhiran -ed atau- $d$ melainkan kata tersebut berubah sesuai kaidah yang ada. Irregular verb adalah kata kerja yang tidak mengikuti aturan yang biasanya digunakan dalam pembentukan kata kerja pada umumnya. Sebaliknya, kata kerja ini memiliki cara individu sendiri dalam menambahkan bentuk kata [2].

Irregular verbs berasal dari periode Inggris kuno yang disebut kata kerja yang kuat dan lemah. Kata kerja yang kuat dibentuk dari past tense dan past participle sedangkan kata kerja yang lemah dibentuk dari past tense dan past participle dengan perubahan akhiran $\mathrm{d}$ atau $\mathrm{t}$, tetapi selama periode Inggris menengah, untuk kata kerja yang lemah menjadi kata kerja reguler dan kata kerja yang kuat menjadi kata kerja tidak teratur [4].

\subsection{Android}

Android adalah sebuah sistem operasi yang dikembangkan untuk perangkat mobile berbasis Linux. Pada awalnya sistem operasi ini dikembangkan oleh Android Inc yang kemudian dibeli oleh Google pada tahun 2005. Fitur yang tersedia pada Android adalah [5] :

a. Framework aplikasi : memungkinkan penggunaan dan pemindahan dari komponen yang tersedia

b. Dalvik virtual machine : virtual machine yang dioptimalkan untuk perangkat mobile

c. Grafik : grafik 2D dan grafik 3D yang didasarkan pada library OpenGL

d. SQLite : untuk penyimpanan data

e. Mendukung media : audio, video, dan berbagai format gambar (MPEG4, H.264 MP3, AAC, AMR, JPG, PNG, GIF)

f. GSM, Bluetooth, EDGE, 3G, and WiFi (tergantung hardware)

g. Camera, Global Positioning System (GPS), compas, dan accelerometer (tergantung hardware)

h. Lingkungan pengembangan yang kaya, termasuk emulator, peralatan debugging, dan plugin untuk Eclipse IDE.

\subsection{Java}

Menurut definisi dari Sun adalah nama untuk sekumpulan teknologi untuk membuat dan menjalankan perangkat lunak pada komputer standalone ataupun pada lingkungan jaringan. Java berdiri di atas sebuah mesin interpreter yang diberi nama Java Virtual Machine (JVM). JVM inilah yang akan membaca bytecode dalam file .class dari suatau program sebagai representasi langsung program yang berisi bahasa mesin [6] 


\subsection{Eclipse IDE}

Eclipse adalah sebuah IDE (Integrated Development Environment) yang digunakan untuk mengembangkan perangkat lunak dan dapat dijalankan di semua platform (platformindependent). Berikut adalah sifat-sifat Eclipse [7] :

1. Multi-platform, target sistem operasi eclipse adalah Microsoft Windows, Linux, Solaris, AIX, HP-UX dan Mac OS X.

2. Multi-language, eclipse dikembangkan dengan bahasa pemrograman java, akan tetapi eclipse mendukung pengembangan aplikasi berbasis bahasa pemrograman lainnya, seperti $\mathrm{C} / \mathrm{C}++$, Cobol, Python, Perl, PHP dan lain sebagainya.

\subsection{SQLite}

SQLite adalah salah satu software yang embedded yang sangat populer, kombinasi SQL interface dan penggunaan memory yang sangat sedikit dengan kecepatan yang sangat cepat". SQLite di Android termasuk dalam Android Runtime, sehingga setiap versi dari Android dapat membuat database dengan SQLite [7].

Dalam sistem android memiliki beberapa teknik untuk melakukan penyimpanan data. Teknik yang umum digunakan adalah sebagai berikut :

1. Shared Prefences yaitu menyimpan data beberapa nilai (value) dalam bentuk groups key yang dikenal dengan prefences.

2. Files yaitu menyimpan data dalam bentuk file, dapat berupa menulis ke file atau membaca dari file.

3. SQLite Databases yaitu menyimpan data dalam bentuk Databases.

4. Content Providers yaitu menyimpan data dalam bentuk content providers service.

\subsection{Unified Modelling Language}

Unified Modelling Language (UML) adalah bahasa permodelan yang telah menjadi standar dalam menunjukkan visualisasi, merancang dan mendokumentasikan sistem perangkat lunak. UML menyediakan standar untuk merancang model sebuah sistem. UML dapat menggambarkan model untuk semua jenis aplikasi yang dapat dijalankan pada berbagai perangkat keras, sistem operasi, dan bahasa pemrograman [8].

\section{Metode Penelitian}

\subsection{Prosedur Penelitian}

Prosedur penelitian yang dilakukan pada aplikasi kamus irregular verbs ini dimulai dari mengidentifikasi masalah mengenai sistem yang sedang berjalan di aplikasi kamus berbasis mobile dan mempelajari bagaimana membuat sebuah aplikasi kamus berbasis mobile berdasarkan literatur yang dijadikan sebagai referensi. Adapun tahapan prosedur penelitian dapat dilihat pada Gambar 1.

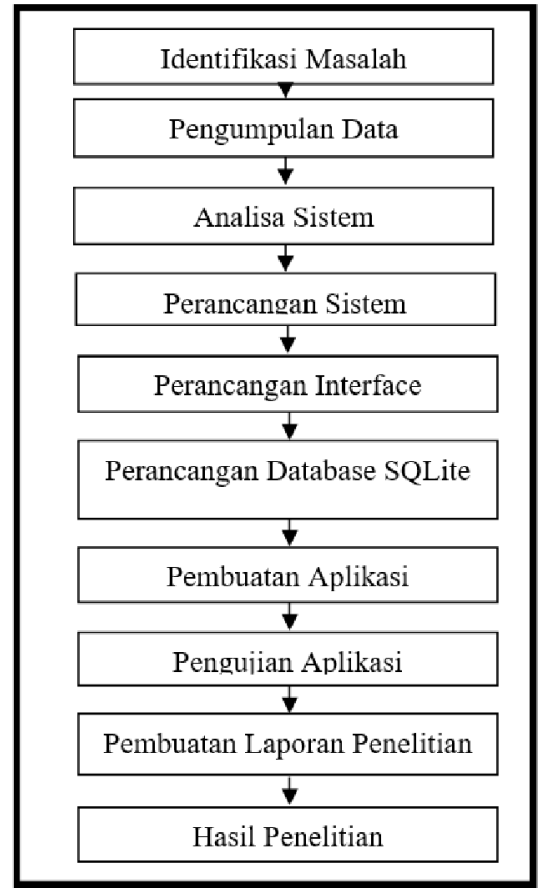

Gambar 1. Prosedur Penelitian

\subsection{Perancangan Sistem}

Perancangan sistem pada penelitian ini menggunakan metode Unified Modeling Language (UML) yang terdiri atas Use Case Diagram, Sequence Diagram dan Activity Diagram.

\section{a. Use Case Diagram}

Use Case Diagram menggambarkan interaksi antara satu atau lebih actor dengan sebuah sistem yang digunakan [9]. Adapun use case diagram pada penelitian ini dapat dilihat pada Gambar 2.

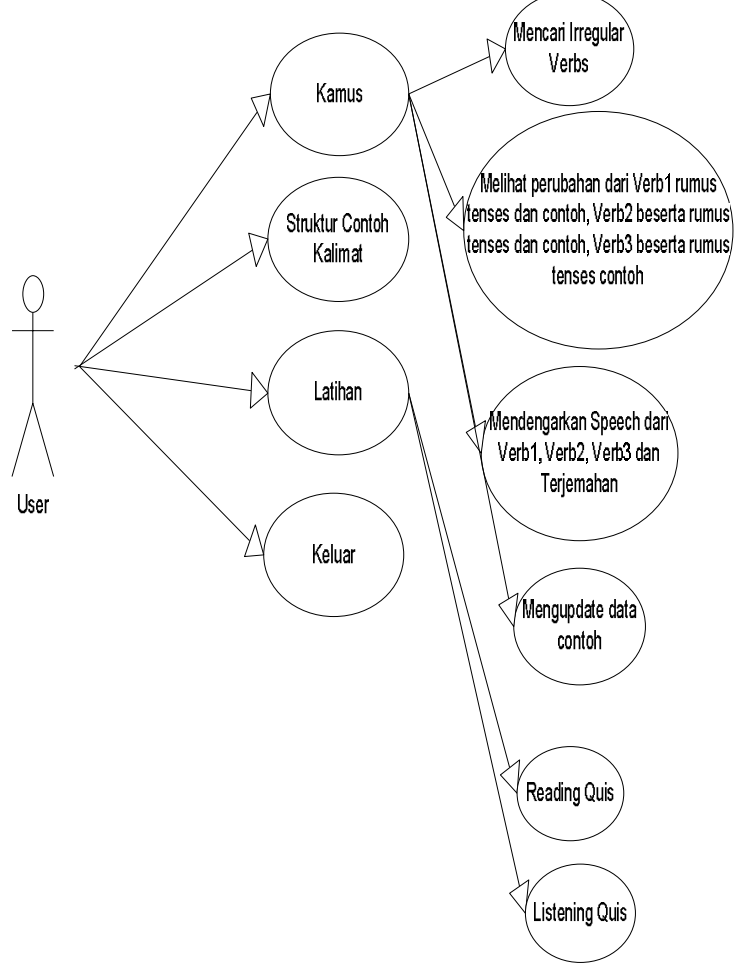


Gambar 2. Use Case Diagram

b. Sequence Diagram

Sequence diagram merupakan model dinamis dari use case diagram, sequence diagram menampilkan interaksi antar objek selama jangka waktu tertentu[10]. Berikut adalah beberapa perancangan sistem menggunakan sequence diagram pada penelitian ini yang dapat dilihat pada Gambar 3, Gambar 4, Gambar 5, dan Gambar 6.

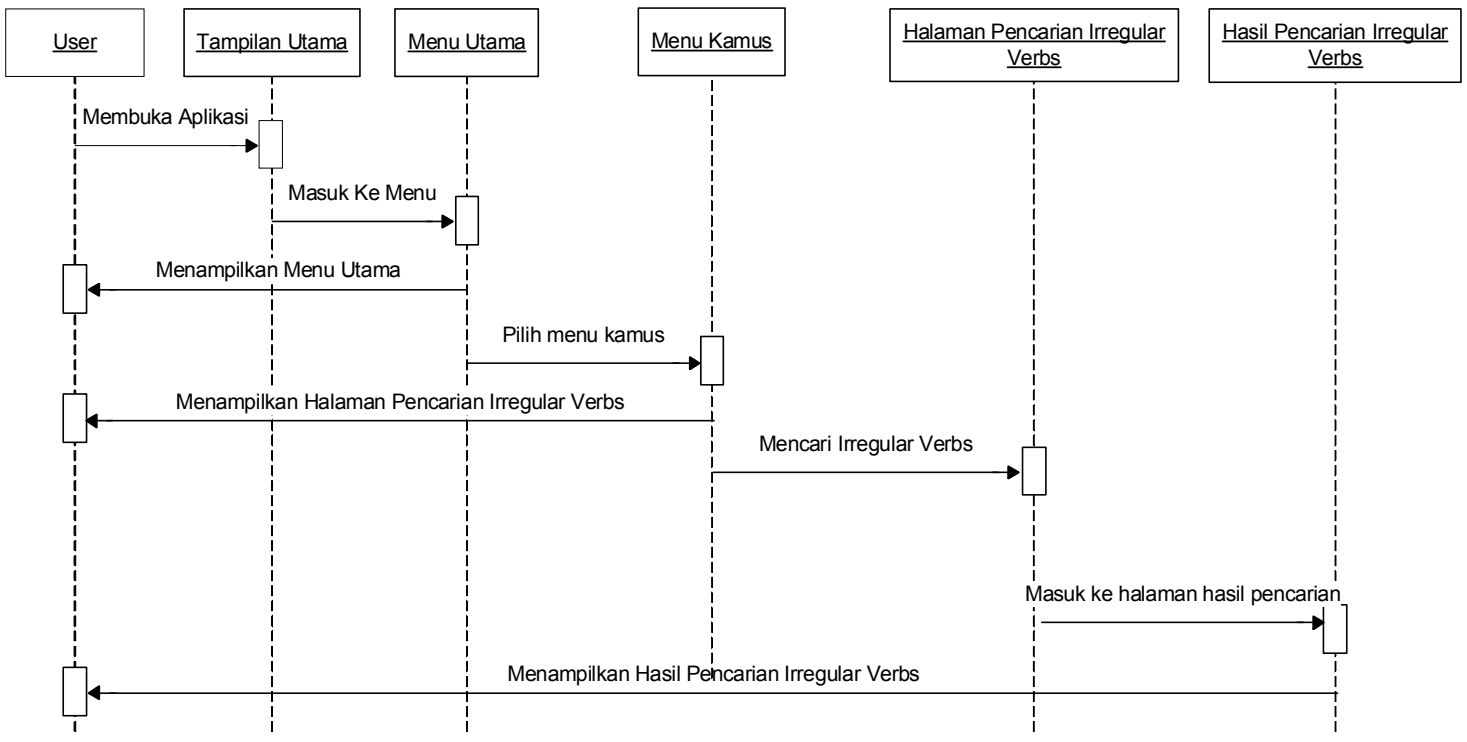

Gambar 3. Sequence Diagram Kamus Irregular Verbs

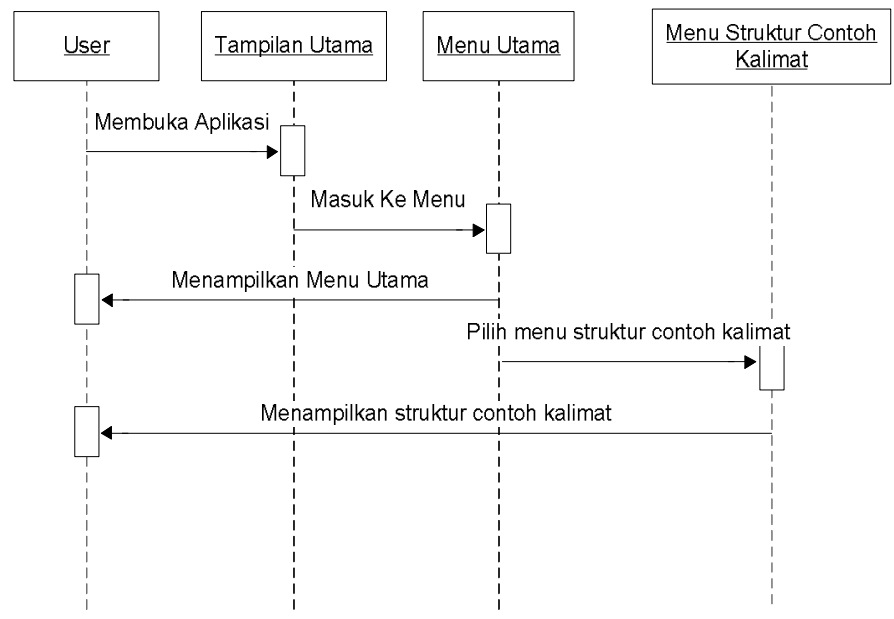

Gambar 4. Sequence Diagram Struktur Contoh Kalimat 


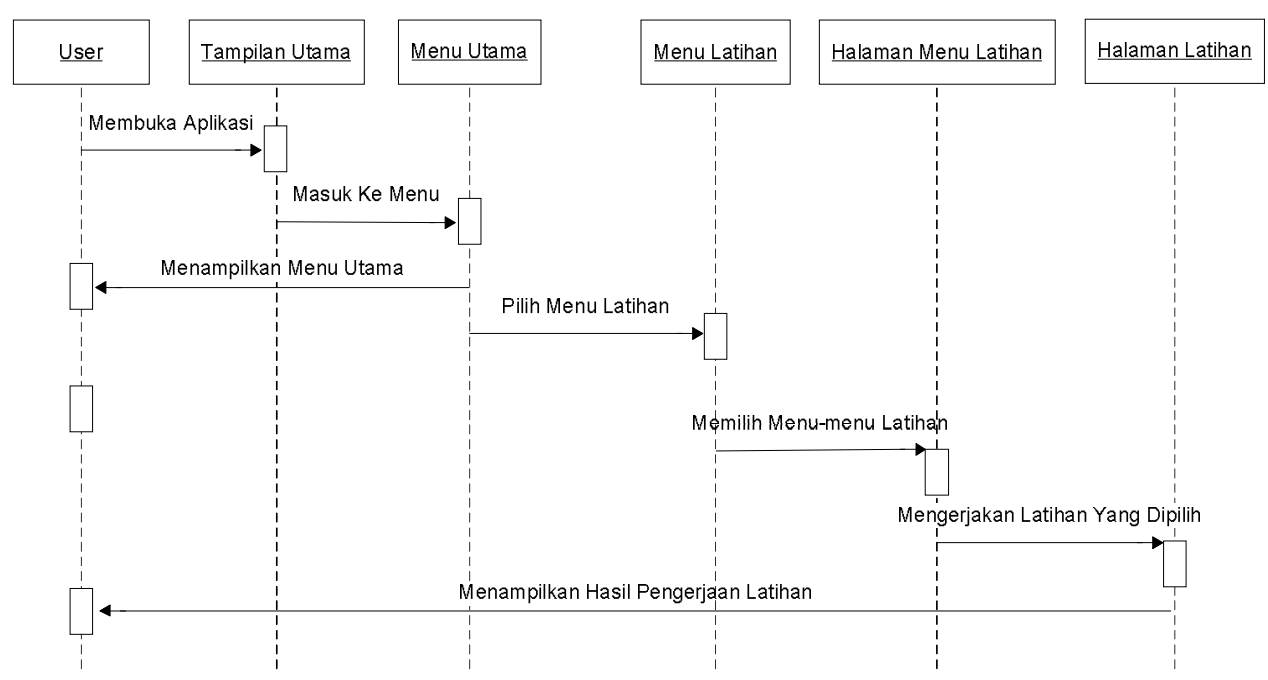

Gambar 5. Sequence Diagram Latihan

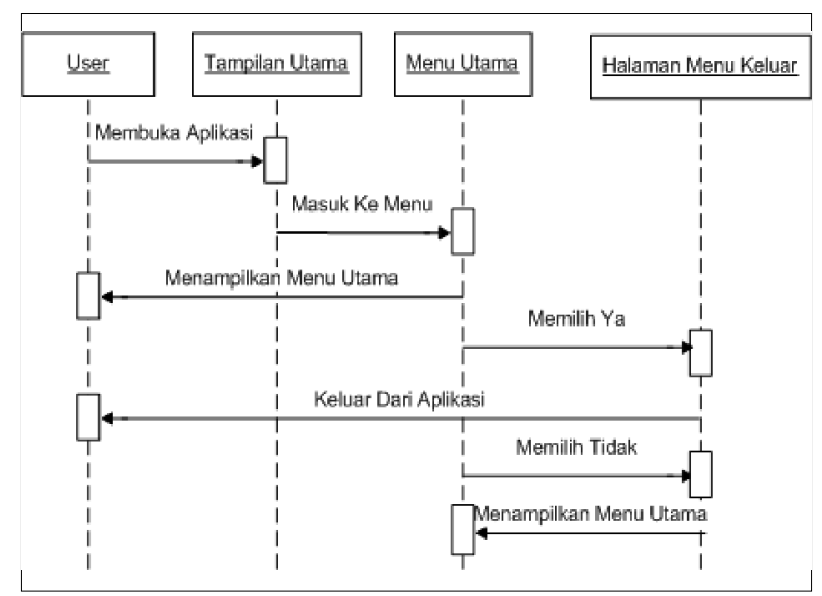

Gambar 6. Sequence Diagram Keluar

\section{c. Activity Diagram}

Activity diagram menggambarkan berbagai aliran aktivitas dalam sistem yang sedang dirancang, bagaimana masing-masing alir berawal, decision yang mungkin terjadi dan akhir dari aktivitas. Activity diagram juga dapat menggambarkan proses paralel yang mungkin terjadi pada beberapa eksekusi [11]. Berikut adalah perancangan sistem yang digambarkan dengan activity diagram dapat dilihat pada Gambar 7, Gambar 8, Gambar 9, dan Gambar 10. 


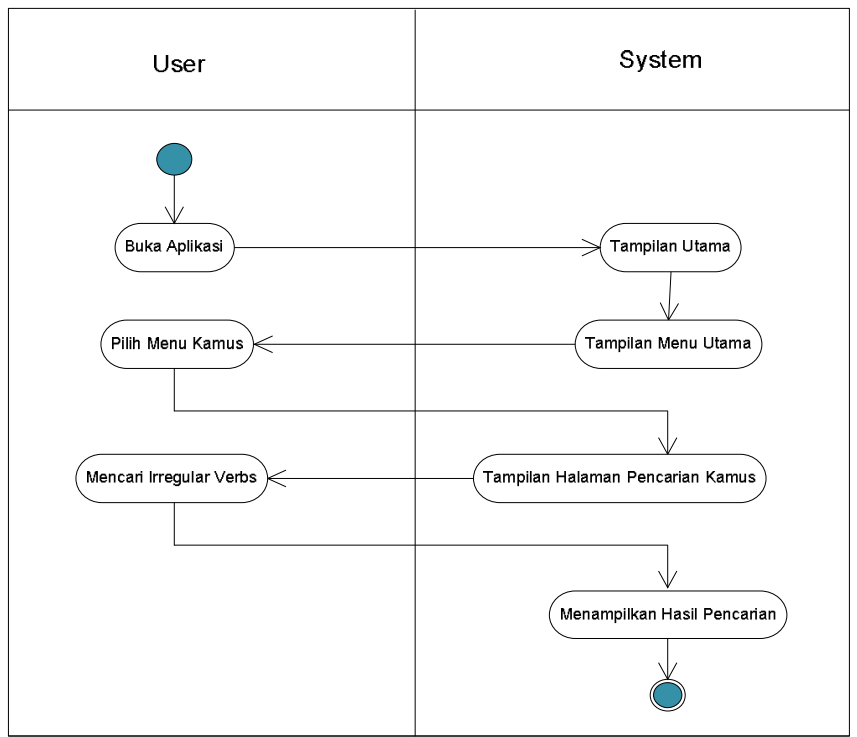

Gambar 7. ActivityDiagram Kamus

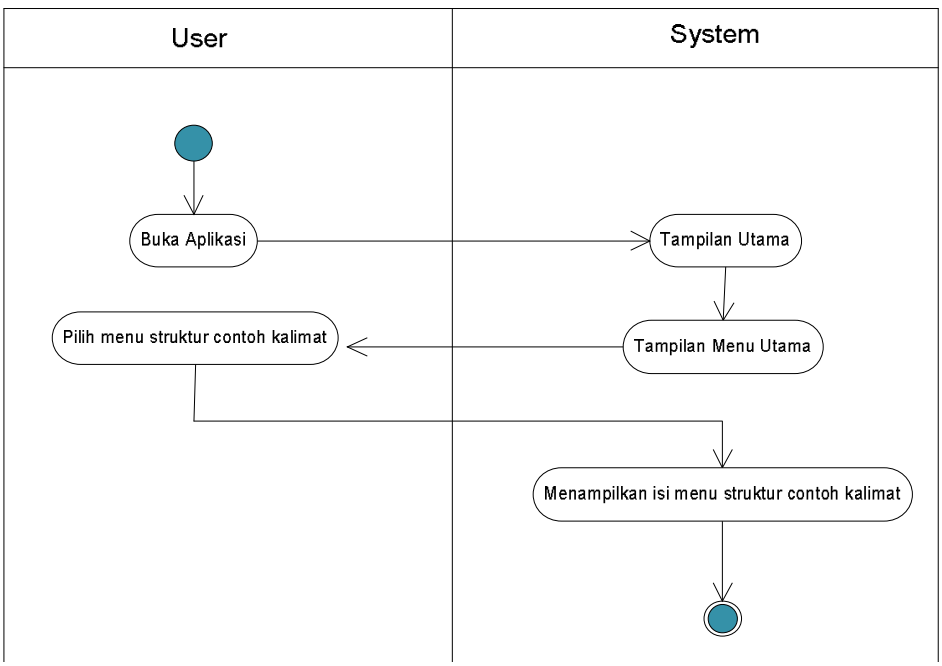

Gambar 8. ActivityDiagram Struktur contoh kalimat 


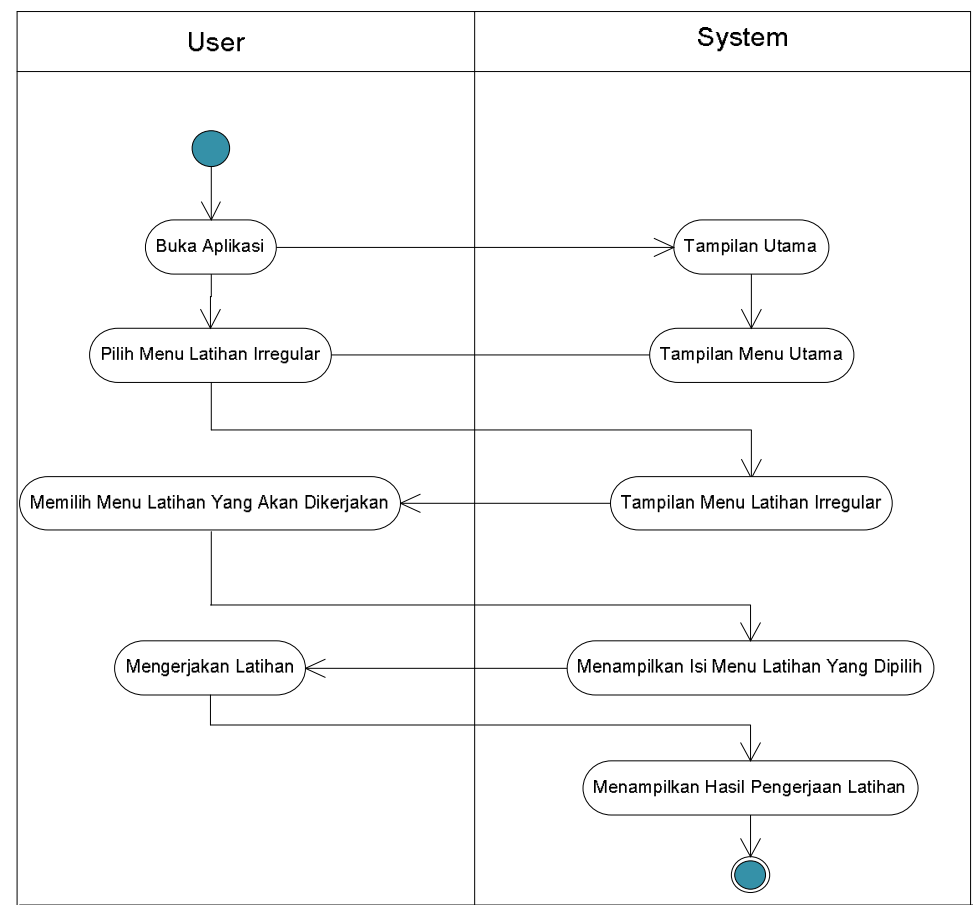

Gambar 9. ActivityDiagramLatihan

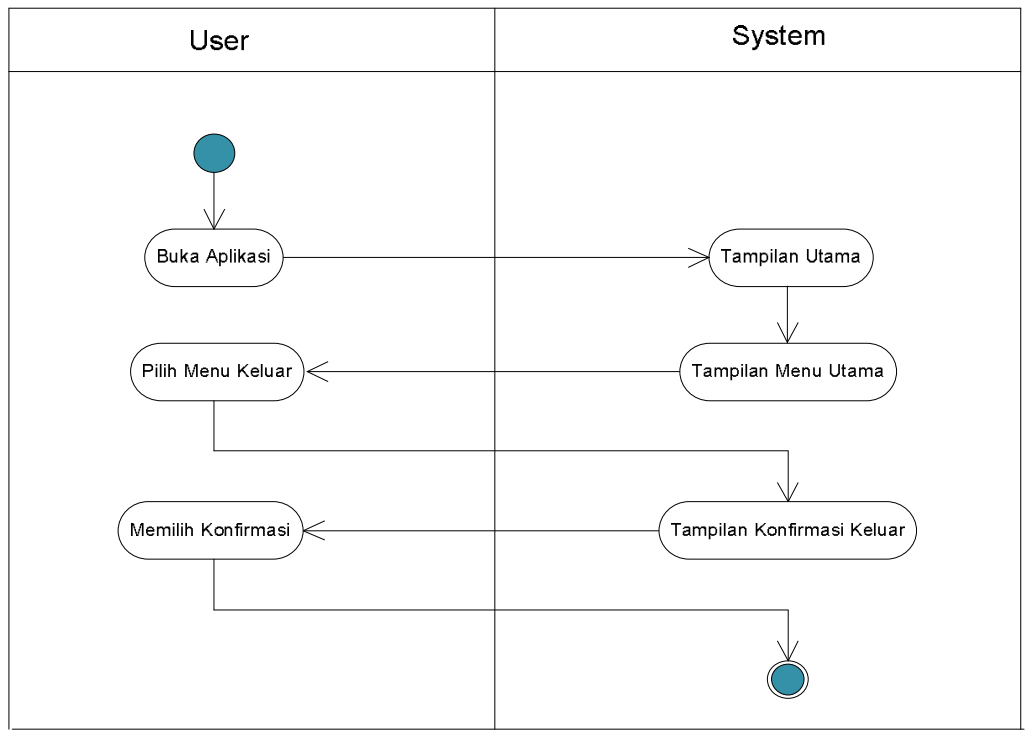

Gambar 10. ActivityDiagramKeluar

\section{Hasil dan Pembahasan}

\subsection{Hasil}

Hasil dari penelitian ini adalah sebuah

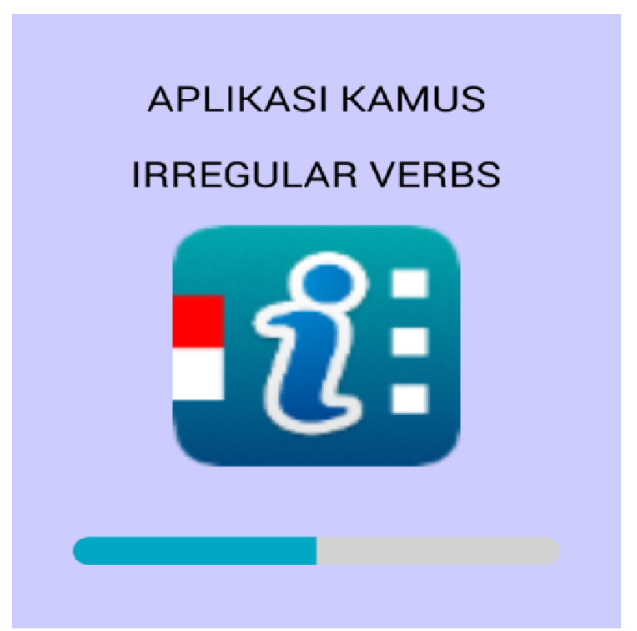

Gambar 11. Antarmuka splash secreen Aplikasi Kamus Irregular Verbs yang dapat dijalankan pada perangkat mobile berbasis android.Berikut adalah hasil antarmuka dari Aplikasi Kamus Irregular Verbs Berbasis Android:

a. Antarmuka splash secreen

Gambar 11 merupakan tampilan yang akan keluar pertama kali ketika aplikasi dijalankan yang disebut dengan splash screen. Pada splash screen mengandung informasi judul aplikasi, logo, dan progress bar loading untuk menampilkan tampilan utama aplikasi. 
b. Antarmuka menu utama

Gambar 12 merupakan tampilan utama yang memuat tombol navigasi. Tampilan ini akan muncul ketika splash secreen telah selesai.

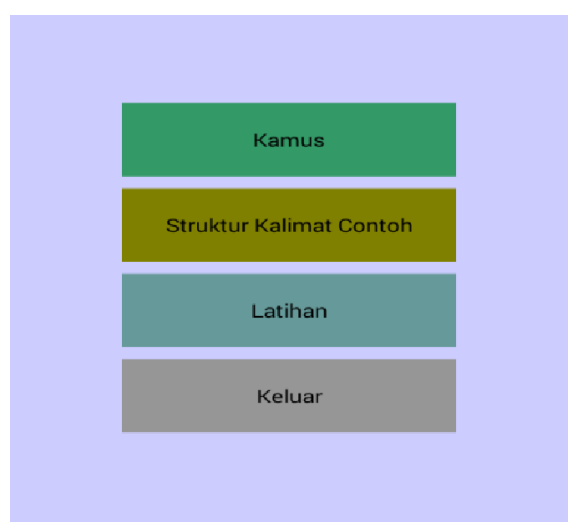

Gambar 12. Antarmuka menu utama

c. Antarmuka daftar kata kerja

Gambar 13 akan muncul ketika menu kamus dipilih, tampilan ini berisi daftar kata kerja yang telah tersimpan didatabase SQLite.

\begin{tabular}{l}
$\leftarrow$ Daftar Kata Kerja \\
Search word \\
Abide \\
Arise \\
Awake \\
Backslide \\
Be \\
Bear \\
Beat \\
Become \\
Befall \\
\hline Beget
\end{tabular}

Gambar 13. Antarmuka daftar kata kerja

d. Antarmuka hasil kamus irregular verbs

Gambar 14 akan muncul ketika dilakukan penekanan pada salah satu daftar kata kerja yang dicari.

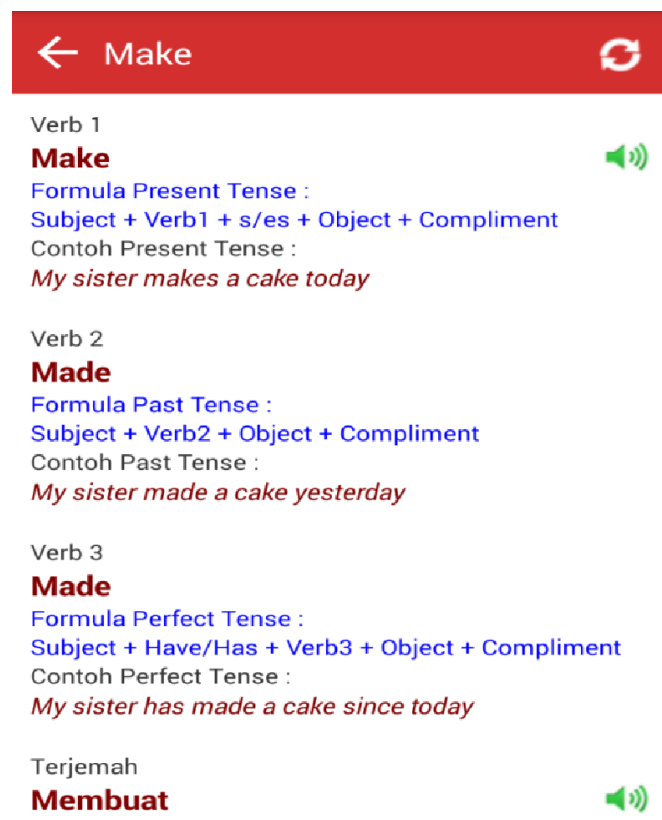

Gambar 14. Antarmuka hasil kamus irregular verbs

e. Antarmuka struktur contoh kalimat

Gambar 15 akan muncul ketika menu struktur contoh kalimat dipilih, menu ini berisi rumusrumus yang digunakan dalam contoh kalimat dari masing-masing verbs.

\section{$\leftarrow$ Struktur}

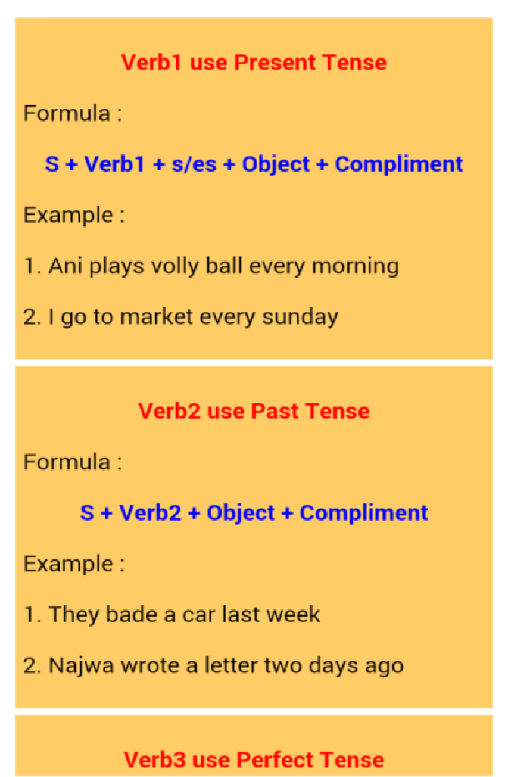

Gambar 15. Antarmuka struktur contoh kalimat

f. Antarmuka latihan

Antarmuka latihan memiliki beberapa tampilan antara lain Gambar 16 untuk tampilan menu latihan atau quis, Gambar 17 untuk tampilan latihan reading dan Gambar 18 untuk tampilan latihan listening. 


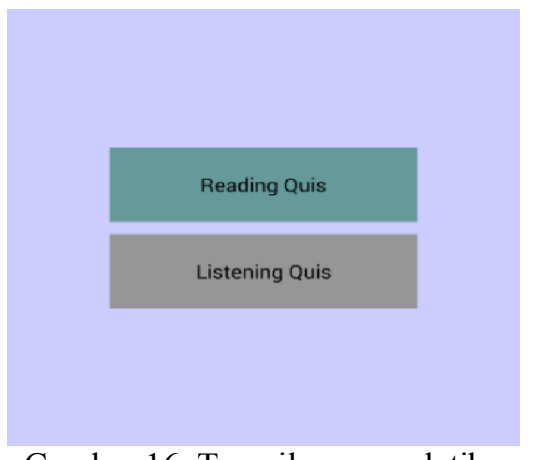

Gambar 16. Tampilan menu latihan

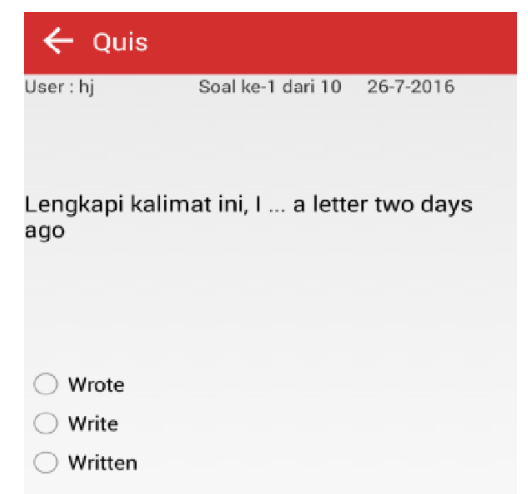

Berikutnya

Gambar 17. Tampilan latihan reading

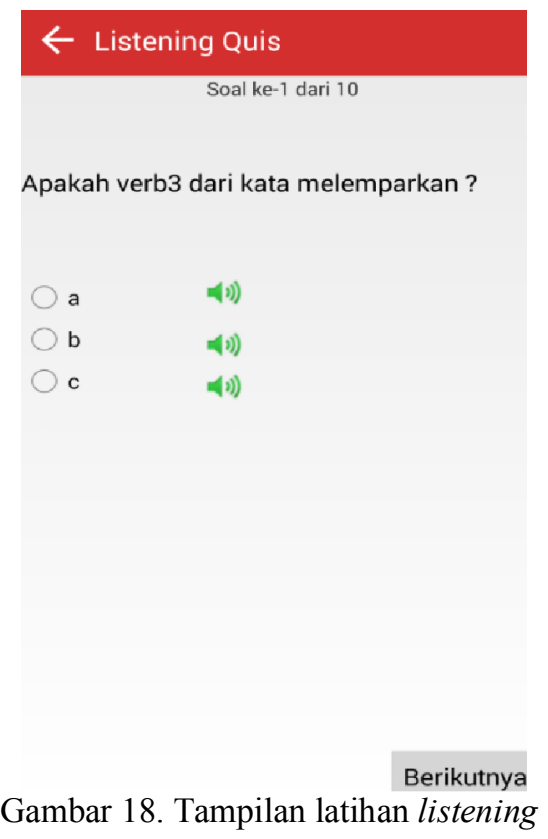

g. Antarmuka keluar
Gambar 19 akan muncul ketika menu keluar dipilih, menu ini menyediakan dua opsi pilihan yaitu keluar dari aplikasi atau tidak.

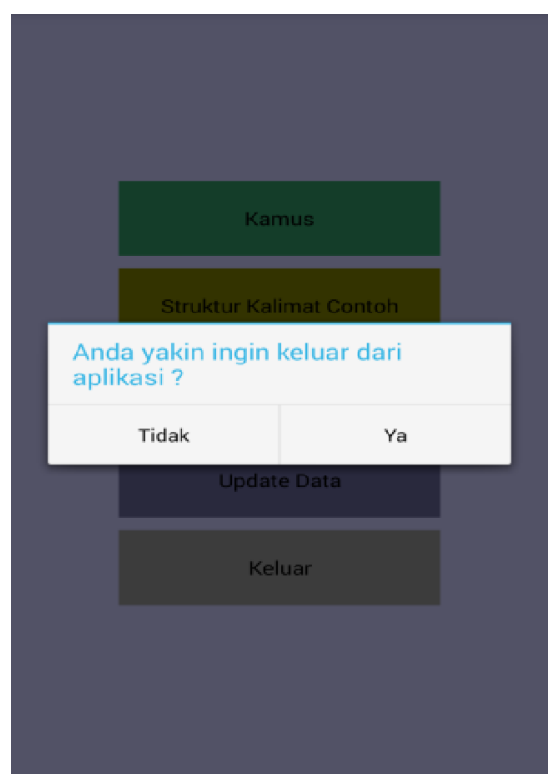

Gambar 19. Antarmuka keluar

\subsection{Pembahasan}

Pengujian aplikasi yang bertujuan untuk mengimplementasikan rancangan yang sudah dibuat dengan menjalankan dan melakukan uji coba pada Aplikasi Kamus Irregular Verbs Berbasis Android.

Agar dapat menggunakan aplikasi ini dengan baik ada dua hal yang perlu diperhatikan, antara lain : untuk menghasilkan suara dengan tata baca Bahasa Indonesia yang baik, perangkat android yang digunakan harus memiliki library Text To Speech tambahan yaitu Google Text To Speech. Namun ada juga perangkat android yang telah terinstall library ini, sehingga tidak perlu menginstall kembali library Google Text To Speech. Selain penggunaan Text To Speech hal yang perlu diperhatikan lagi dalam menggunakan Aplikasi Kamus Irregular Verbs Berbasis Android ini adalah koneksi internet, koneksi internet ini digunakan untuk mengupdate contoh ke server sehingga perangkat android yang digunakan harus memiliki koneksi internet yang baik. Berikut Tabel 1 hasil pengujian aplikasi menggunakan perangkat mobile andoid.

Tabel 1. Pengujian Aplikasi Menggunakan Perangkat Mobile Android

\begin{tabular}{|c|c|c|c|c|c|}
\hline \multirow{2}{*}{$\begin{array}{l}\mathbf{N} \\
\mathbf{0}\end{array}$} & \multicolumn{4}{|c|}{ Spesifikasi Perangkat Android } & \multirow{2}{*}{ Hasil } \\
\hline & OS & CPU & RAM & LCD & \\
\hline 1 & $\begin{array}{l}\text { Android } \\
2.3 .4 \\
\text { Ginger } \\
\text { Bread }\end{array}$ & $\begin{array}{l}\text { Single } \\
\text { Core } \\
1.0 \\
\mathrm{GHz} \\
\end{array}$ & $\begin{array}{l}512 \\
\mathrm{MB}\end{array}$ & $\begin{array}{l}3.3 \\
\text { inch }\end{array}$ & $\begin{array}{l}\text { Aplikasi } \\
\text { Tidak } \\
\text { Berjalan }\end{array}$ \\
\hline 2 & Android & Quad- & $1 \mathrm{~GB}$ & 4.7 & Aplikasi \\
\hline
\end{tabular}




\begin{tabular}{|l|l|l|l|c|c|} 
& $\begin{array}{l}4.3 \\
\text { Jelly } \\
\text { Bean }\end{array}$ & $\begin{array}{l}\text { core } \\
1.6 \\
\text { GHz }\end{array}$ & & inch & $\begin{array}{c}\text { Berjalan } \\
\text { Baik }\end{array}$ \\
\hline \multirow{4}{*}{3} & $\begin{array}{l}\text { Android } \\
4.4 .2 \\
\text { KitKat }\end{array}$ & $\begin{array}{l}\text { Quad- } \\
\text { core } \\
1.2 \\
\text { GHz }\end{array}$ & $1 \mathrm{~GB}$ & $\begin{array}{c}4.7 \\
\text { inch }\end{array}$ & $\begin{array}{c}\text { Aplikasi } \\
\text { Berjalan } \\
\text { Baik }\end{array}$ \\
\hline \multirow{4}{*}{4} & $\begin{array}{l}\text { Android } \\
4.4 .2 \\
\text { KitKat }\end{array}$ & $\begin{array}{l}\text { Quad- } \\
\text { core } \\
1.2 \\
\text { GHz }\end{array}$ & $2 \mathrm{~GB}$ & 4.7 & $\begin{array}{c}\text { Aplikasi } \\
\text { Berjalan } \\
\text { inch }\end{array}$ \\
\hline
\end{tabular}

\section{Kesimpulan dan Saran}

\subsection{Kesimpulan}

Berdasarkan hasil penelitian yang telah dilakukan dapat diambil kesimpulan bahwa Aplikasi Kamus Irregular Verbs Berbasis Android ini dapat berjalan pada perangkat android mulai dari versi 4.3 hingga versi terbaru. Untuk menggunakan aplikasi ini dengan baik ada dua hal yang perlu diperhatikan oleh pengguna, antara lain Untuk menghasilkan suara dengan tata baca Bahasa Indonesia yang baik, perangkat android yang digunakan harus memiliki library Text To Speech tambahan yaitu Google Text To Speech. Namun ada juga perangkat android yang telah terinstall library ini, sehingga tidak perlu menginstall kembali library Google Text To Speech. Selain penggunaan Text To Speech hal yang perlu diperhatikan lagi dalam menggunakan Aplikasi Kamus Irregular Verbs Berbasis Android ini adalah koneksi internet, koneksi internet ini digunakan untuk mengupdate contoh dari server sehingga perangkat android yang digunakan harus memiliki koneksi internet yang baik.

\subsection{Saran}

Pada Aplikasi Kamus Irregular Verbs Berbasis Android ini hanya menyediakan kamus irregular verbs dari Inggris ke Indonesia, untuk saran dalam pengembangan Aplikasi ini agar lebih baik yaitu, adanya penambahan menu kamus irregular verbs dari Indonesia ke Inggris sehingga lebih memudahkan pengguna dalam pencarian irregular verbs.

\section{Daftar Pustaka}

[1] Hamka, D., Sobri, M., Rizal, S., 2012, Aplikasi Kamus Inggris - Indonesia Indonesia - Inggris Pada Platform Android, Universitas Bina Darma.

[2] Adia, J., 2011, Langsung Bisa Menguasai Grammar, Agogos Publishing, Jakarta.

[3] Siregar, J., 2013, Perancangan Aplikasi Pencarian Kata Kamus Bahasa Inggris Ke Bahasa Indonesia Dengan Menggunakan Algoritma Brute Force Berbasis Mobile, Pelita Informatika Budi Darma, Volume: $V$, Nomor: 3, 75-76.
[4] O'Dwyer, Bernard. 2006. Modern English Structures: Form, Function, And Position, 2nd ed. Broadview Press.

[5] Hermawan, S., 2011, Mudah Membuat Aplikasi Android, Andi, Yogyakarta.

[6] Shalahuddin, M., Rosa, A.S., 2010, Pemrograman J2ME (Belajar Cepat Pemrograman Perangkat Telekomunikasi Mobile), Ed. II, Informatika, Bandung.

[7] Safaat, N., 2012, Pemrograman Aplikasi Mobile Smartphone dan Tablet PC Berbasis Android, Informatika, Bandung.

[8] Sulistyorini, P., 2009, Pemodelan Visual dengan Menggunakan UML dan Relational Rose, Jurnal Teknologi Informasi DINAMIK, (14) 1, 23-29.

[9] Kendall, K, E., Kendall, J, E., 2011, System Analysis and Design, Canada: Pearson International Edition.

[10] Sholiq (2006), Pemodelan Sistem Informasi Berorientasi Obyek Dengan UML,Graha Ilmu, Yogyakarta.

[11] Fadlullah, M., 2012, Rancang Bangun Aplikasi Kamus Jerman - Indonesia Berbasis Android, Tugas Akhir, Teknik Informatika, Fakultas Teknologi Informasi Universitas Stikubank (Unisbank) Semarang. 